\title{
ASSESSMENT OF COMMON MATERNAL RISK FACTORS IN FETAL MALNUTRITION
}

\author{
Anshu Poudel ${ }^{1 *}$, Nisha K Bhatta ${ }^{2}$, Mohan Chandra Regmi $^{3}$, Lokraj Shah ${ }^{4}$, Rajan Paudel ${ }^{1}$
}

\section{Affiliation}

1. DM Senoir Resident (Neonatology), Department of Paediatrics, B.P Koirala Institute of Health Sciences (BPKIHS), Nepal.

2. Professor, Division of Neonatology, Department of Paediatrics, B.P Koirala Institute of Health Sciences (BPKIHS), Nepal.

3. Professor, Department of Gynecology and Obstetrics, B.P Koirala Institute of Health Sciences (BPKIHS), Nepal.

4. Assistant Professor, Department of Paediatrics, B.P Koirala Institute of Health Sciences (BPKIHS), Nepal.

\section{ARTICLE INFO}

Received : 02 February, 2021
Accepted $: 28$ March, 2021
Published : 15 June, 2021

(C) Authors retain copyright and grant the journal right of first publication with the work simultaneously licensed under Creative Commons Attribution License CC - BY 4.0 that allows others to share the work with an acknowledgment of the work's authorship and initial publication in this journal.

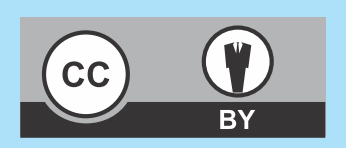

ORA 238

DOI: https://doi.org/10.3126/bjhs.v6i1.37641

\author{
* Corresponding Author \\ Dr. Anshu Poudel \\ DM Senior Resident (Neonatology) \\ Department of Paediatrics \\ B.P Koirala Institute of Health Sciences (BPKIHS), Nepal \\ Email:dranshupoudel@gmail.com \\ ORCID: https://orcid.org/0000-0001-8556-2667
}

\section{Citation}

Anshu Poudel, Nisha K Bhatta, Mohan Chandra Regmi, Lokraj Shah, Rajan Paudel. Assessment of Common Maternal Risk Factors in Fetal Malnutrition. BJHS 2021;6(1)14.1377-1382.

\section{ABSTRACT \\ Introduction}

Nutritional assessment of the newborn gives the reflection of the growth process in the intrauterine period. The Clinical Assessment of Fetal Nutritional Status score (CAN score) method is only the method to assess the fetal malnutrition which includes the clinical observation for the presence of the sign of malnutrition in newborns. Since the fetal growth is related to availability of intrauterine nutrition and placental function, there may be several maternal factors associated with the fetal malnutrition.

\section{Objectives}

The main objective of the study was to determine the prevalance of Fetal Malnutrition in term newborns and the role of maternal factors in the etiology of fetal malnutrition (FM) in the Neonatal and Maternity Units of B.P Koirala Institute of Health Sciences, Dharan.

\section{Methodology}

This was a hospital based observational cross sectional study of consecutive, singleton, term live babies delivered between September 2019 to March 2020. Fetal malnutrition was diagnosed using Clinical Assessment of Fetal Nutritional Status score (CAN score) developed by Metcoff. The maternal history was obtained from the mother which included age, parity, socioeconomic class, pre pregnancy weight, number of antenatal care during pregnancy, history of maternal illness and drugs taken during pregnancy. Nutritional status of the mother was determined using weight, height, mid arm circumference (MAC) and the body mass index (BMI). Collected data was entered in Microsoft excel 2010 and converted it into SPSS 23 version software, for statistical analysis.

\section{Results}

Of the 400 studied newborns, 73 [18\%] had FM. The prevalence of teenage pregnancy, primiparity, lower maternal mid arm circumference and vegetarian diets were higher in the mothers of the babies who had suffered fetal malnutrition than the mothers of the babies without FM ( $p$ value $<0.05$ ). The adverse maternal condition like Pregnancy induced hypertension (PIH), Antepartum hemorrahge (APH), Urinary tract infection (UTI), fever during pregnancy had significant impact in the fetal malnutrition( $p$ value $<0.05$ ).

\section{Conclusion}

Improvement in the socioeconomic condition of women and good antenatal care could reduce most of the maternal factors associated with fetal malnutrition. There should be implementation of more accessible programs which address the issues of the maternal nutrition and the maternal health care in Nepal.

\section{KEYWORDS}

CANSCORE, fetal malnutrition, maternal risk factor 


\section{INTRODUCTON}

The fetal growth is related to placental function, growth potential of the fetus and the availability of intrauterine nutrition. To assess the fetal nutritional status, the methods like Birth weight criteria, intrauterine growth chart, ponderal index are used commonly in the early neonatal period. ${ }^{1-4}$ The terminologies used for poor nutritional status are low birth weight babies, small for gestational age babies etc. Since most of the methods used for assessing the nutritional status, make use of the anthropometric measures with or without the corresponding gestational age, it may or may not be able to diagnose the poor nutritional status clinically. ${ }^{5}$ It has been noted in many studies that all the SGA babies are not malnourished and AGA can also be malnourished. ${ }^{6}$ It is important to know nutritional status of the newborn babies by other methods of examination.

The clinical method to assess the fetal malnutrition scoring method known as Clinical Assessment of Nutrition score (CAN score) was developed by Jack Metcoff in the year 1994. The method is based on clinical evidences of malnutrition in term babies and the nutritional status is determined by inspection and hands-on estimates of loss of subcutaneous tissues and muscles. This scoring system evaluates the different parts of the newborn baby rather than relying solely on the anthropometric measures. Hence, this method gives the best estimates of the fetal malnutrition status, where a fetus fails to acquire adequate quantum of fat and muscle mass during intrauterine growth.

The adverse fetal nutritional state has been associated with both short and long term adverse outcome. Fetal Malnutrition predisposes to perinatal deaths due to fetal distress, meconium aspiration, asphyxia and postpartum hypoglycemia, hyper-viscosity syndrome etc. in the neonatal period.$^{8-10}$ The studies have shown that babies who have suffered intrauterine malnutrition had neurologic disability, intellectual disability, learning disorders, language delay or seizures disorders in the later life..$^{11-14}$ The world renowned hypothesis "fetal origin of adult disease" by Barker et al, also implicates the association of fetal malnutrition with metabolic diseases like obesity, hypertension, diabetics mellitus etc. Since different tissues mature during different periods of fetal life and infancy, the long term consequences of altered nutrition depend on its timing and duration. ${ }^{15}$

As the fetal adverse nutritional status is associated with morbidities and mortality, many studies have been conducted to find the association of maternal factors with the fetal malnutrition. Different studies have shown that multiple factors are related for the proper growth and development of fetus. The factors that are associated with fetal malnutrition include age of the mother, ethnicity, education, psychological state, parity, maternal nutritional status, presence of acute and chronic illness, etc. ${ }^{8,16}$ There might be still unknown maternal factors that has implication in the fetal nutritional status.

The terminologies like low birth weight and SGA are most commonly used worldwide to assess the fetal nutritional status. But the true evidence of fetal malnutrition can be detected by the CANscore. Many literatures have shown that all SGA babies have not suffered from fetal malnutrition and some AGA babies have shown the evidence of fetal malnutrition. Since, there is paucity of the literature regarding the prevalence of the fetal malnutrition, using CANscore method, in our country. This study was conducted to see the prevalence of fetal malnutrition and its association with the maternal risk factors.

\section{METHODOLOGY}

This cross sectional observational study was conducted over the period of 6 months September 2019 to March 2020 in the maternity and neonatal units of B.P Koirala Institute of Health Sciences (BPKIHS), Dharan, Nepal. There is paucity of the data regarding the prevalence of the fetal malnutrition using CAN score and most of the literatures have used SGA criteria for defining the fetal nutritional status. According to the literature the prevalence of SGA babies ranged from 10.5 to 72.5 percent in Nepal. ${ }^{17}$ Taking the prevalence of $50 \%$, we calculated our sample size to be 384 , using Daniel method. ${ }^{18}$ Ethical approval was obtained from the Institutional Review committee (IRC) of BPKIHS.

The subjects were consecutive, singleton, live birth, term (3742 weeks of gestation) neonates delivered at the maternity unit of BPKIHS, Dharan. Babies with congenital anomalies were excluded from the study.

Written informed consent was taken in local language. Detailed demographic and clinical profile was taken for those who fall in the inclusion criteria and was entered in the predesigned proforma. The required maternal history was taken and entered in the predesigned proforma. The maternal data included hospital number, name, age, weight, height, Body mass index, parity, socioeconomic status of the mother, date of last menstrual period, parity, place of antenatal care, number of clinic attendances, duration of pregnancy, associated maternal risk factors/co morbidities.

The newborns were assessed clinically between $24-48$ hours on the basis of the superficial readily detectable signs of malnutrition in the newborn using the clinical assessment of nutrition (CAN) rating as described by Metcoff. A score of $<25$ was used to define malnutrition (CANscore). Each attribute was scored based on specific described criteria from 1 to $4 ; 1$ being the maximum evidence of malnutrition and 4 being the evidence of good nutrition. The CAN score ranges between 9 as the lowest score and 36 as the highest score. Any score less than 25, was suggestive of malnutrition. Collected sample was entered in Microsoft excel 2010 and converted it into SPSS 23 version for statistical analysis.

\section{RESULTS}

In the study period of 6 months, September 2019 to March 2020 , the total of 400 term newborns was included to assess for fetal malnutrition. Among the 400 newborns, the percentage of the male and female newborns was 51.5 and 48.5 respectively. The maximum number of baby was born at 40th week of gestation which was $30.3 \%$. The total number of neonates born via spontaneous vaginal delivery (SVD), lower segment caesarean section (LSCS) and vacuum assisted vaginal delivery (VAVD) were 222(55.5\%), 171 $(42.8 \%)$ and $7(1.7 \%)$ respectively.

Using the CAN score, $73(18 \%)$ of the newborn were categorized as malnourished (FM) and the rest 327 (82\%) newborns were categorized as well nourished (WN). 


\begin{tabular}{|c|c|c|c|}
\hline $\begin{array}{l}\text { Baseline } \\
\text { characteristics }\end{array}$ & Category & Frequency & Percentage \\
\hline \multirow{2}{*}{ Sex } & Male & 206 & 51.5 \\
\hline & Female & 194 & 48.8 \\
\hline \multirow{6}{*}{$\begin{array}{l}\text { Gestational } \\
\text { age }\end{array}$} & 37 WOG & 36 & 9 \\
\hline & 38 WOG & 72 & 18 \\
\hline & 39 WOG & 108 & 27 \\
\hline & 40 WOG & 121 & 30.3 \\
\hline & 41 WOG & 40 & 10 \\
\hline & 42 WOG & 23 & 5.8 \\
\hline \multirow{3}{*}{$\begin{array}{l}\text { Mode of } \\
\text { delivery }\end{array}$} & SVD & 222 & 55.5 \\
\hline & LSCS & 171 & 42.8 \\
\hline & Vaccum & 7 & 1.7 \\
\hline \multirow{2}{*}{$\begin{array}{l}\text { Nutritional } \\
\text { status }\end{array}$} & Well nourished & 327 & 82 \\
\hline & Mal nourished & 73 & 18 \\
\hline
\end{tabular}

The mean age of the mother of the newborns with FM was less than those without FM. The anthropometric measure of the mother also had significant impact on fetal malnutrition. The FM was observed to be higher in the mothers who had less pre pregnancy weight and height. The other maternal factor like body mass index (BMI) and Mid Arm Circumference was also significantly higher in the mother of newborns without FM as compared to the mother with FM babies. More importantly, the average weight gain in the pregnancy in the mothers with FM was $8.07 \mathrm{~kg}$, which was lower as compared to the mothers without FM which was 9.96 with $p$ value of $<0.001$. The comparison of various the maternal baseline characteristics among the newborns with fetal malnutrition and without fetal malnutrition is shown in Table 2.

Similarly, the FM was significantly higher among the babies born to mothers who were teenage, primipara, and vegetarian as shown in Table 3.

Table 2: Comparison of the maternal baseline characteristics between babies with FM and those without FM

\begin{tabular}{|l|l|l|l|}
\hline Variable & With FM & Without FM & P value \\
\hline Age (years). Mean(SD) & $24.25(4.63)$ & $25.86(4.64)$ & 0.008 \\
\hline Height (cm), Mean (SD) & $152.32(5.41)$ & $153.98(5.85)$ & 0.001 \\
\hline $\begin{array}{l}\text { Pre pregnancy weight (kg), } \\
\text { Mean (SD) }\end{array}$ & $50.89(6.28)$ & $53.94(7.32)$ & 0.026 \\
\hline BMI, Mean(SD) & $21.96(2.53)$ & $22.80(2.99)$ & 0.027 \\
\hline MAC(cm),Mean(SD) & $22.93(2.94)$ & $23.64(2.32)$ & 0.026 \\
\hline $\begin{array}{l}\text { Weight gain in pregnancy } \\
\text { (kg), mean (SD) }\end{array}$ & $8.07(3.76)$ & $9.96(4.58)$ & 0.001 \\
\hline
\end{tabular}

Table 3: Prevalence of the factors associated in pregnancy among the babies with and without fetal malnutrition

\begin{tabular}{|l|c|r|r|}
\hline Variable & $\begin{array}{c}\text { Babies with } \\
\text { FM N(\%) }\end{array}$ & $\begin{array}{c}\text { Babies } \\
\text { without FM } \\
\text { N(\%) }\end{array}$ & P value \\
\hline Teenage mother & $10(13.7)$ & $20(6.1)$ & 0.026 \\
\hline Primiparirty & $43(58.9)$ & $147(45)$ & 0.031 \\
\hline ANC & $12(16.4)$ & $36(11)$ & 0.197 \\
\hline $\begin{array}{l}\text { Socioeconomic } \\
\text { class (lower class) }\end{array}$ & $11(15.1)$ & $46(4.1)$ & 0.7 \\
\hline $\begin{array}{l}\text { Food habit } \\
\text { (vegetarian) }\end{array}$ & $12(16.4)$ & $12(3.7)$ & $12(3.7)$ \\
\hline
\end{tabular}

The presence of the adverse maternal condition like Pregnancy Induced Hypertension (PIH), Antepartum Hemorrhage (APH), Urinary Tract Infection (UTI), and fever during pregnancy had significant impact in fetal malnutrition. Similarly, the prevalence of maternal DM and HIV was higher in malnourished group but the $p$ value was not significant.

Table 4: The maternal disease condition associated in
pregnancy among the mothers of babies with and without
fetal malnutrition
\begin{tabular}{|l|l|l|l|}
\hline Variable & $\begin{array}{c}\text { Babies } \\
\text { with FM } \\
\text { N(\%) }\end{array}$ & $\begin{array}{r}\text { Babies without } \\
\text { FM } \\
\text { N(\%) }\end{array}$ & P value \\
\hline $\begin{array}{l}\text { Pregnancy } \\
\text { induced } \\
\text { Hypertension }\end{array}$ & $13(17.8)$ & $27(8.3 \%)$ & 0.014 \\
\hline DM & $6(8.2)$ & $16(4.9)$ & 0.26 \\
\hline APH & $9(12.3)$ & $6(1.8)$ & $<0.001$ \\
\hline UTI & $5(6.8)$ & $6(1.8)$ & 0.018 \\
\hline Anemia & $4(5.5)$ & $19(5.8)$ & 0.913 \\
\hline HIV & $2(2.7)$ & $2(0.6)$ & 0.98 \\
\hline HBsAg & $3(4.1)$ & $2(0.6)$ & 0.015 \\
\hline Fever & $6(8.2)$ & $10(3.05)$ & 0.04 \\
\hline
\end{tabular}

\section{DISCUSSION}

In this cross sectional observational study, the 400 term newborns were included. Using the Clinical Assessment of the Nutritional Score (CANscore), we found 73 (18.2\%) term neonates had clinical evidence of the Fetal Malnutrition. The similar results were also reported in the Indian population in the different study conducted bySinghal et $\mathrm{al}^{19}{ }^{19}$ Deodhar et al, ${ }^{20}$ Faheem et al, ${ }^{21}$ and Soundhaya et al ${ }^{22}$ ranging from 17.5 to $24 \%$.Similarly, the prevalence of fetal malnutrition was found to be $18 \%$ in the Nigerian population in the study conducted by Adebami et al. ${ }^{8}$ However, the prevalence of FM was found to be low with the value of $7.6 \%$ in the study conducted in Spain. ${ }^{23}$ The variation of the results among the various populations may be due to lack of adequate maternal health care and nourishment in the developing countries as compared to developed nations.

In Nepal, there is paucity of literature for the prevalence of the FM. The poor nutritional status of the fetus is described by the use of terminology like LBW and SGA. According to the literature, the prevalence of LBW in Nepal is $11.2 \% .{ }^{24}$ The SGA in Nepal ranges from $10-72 \% .{ }^{17}$ The low birth weight, SGA criteria cannot be used to assess the fetal malnutrition. The various studies have shown that even in the AGA babies, there may be presence of fetal malnutrition. ${ }^{7,23,25}$ So, all the neonates should be evaluated clinically from head to toe, assessing the texture and fullness of hairs to the acquired muscle mass and fats in different part of the body, while assessing the fetal nutritional status .

We observed the mean difference of various maternal factors like age of the mother, height of the mother, prepregnancy weight, BMI, mid arm circumference and weight gain during pregnancy was statistically significant between the mother of neonates with fetal malnutrition and without 
FM. In other words mean age of the mother, height, pre pregnancy weight, BMI, MAC and weight gain in the pregnancy was lower in the mother with malnourished babies. The study done by Adebami et al in Nigerian population has also shown similar results. ${ }^{8}$ The maternal weight, height, BMI and MAC are the indicators for the maternal nutritional status. Since the fetal growth also depends on the availability of the nutrients from the mother transplancentally, the malnourished mother has inadequate supply of the nutrients to their fetus predisposing them to the adverse environment. The study done by Skokic et al evaluating the association of Low Birth Weight with maternal socio-demographic status during 1992-1995 war period in Bosnia had shown that poor socioeconomic condition and poor nutritional status of mothers during the war period has resulted in the higher number of LBW babies as compared to normal period in Bosnia. ${ }^{26}$ The maternal under-nutrition not only increases the risk of fetal malnutrition and impaired development but also perpetuates an intergenerational vicious cycle of malnutrition.

Similarly the study done by Adebami et al, ${ }^{8}$ the maternal factors like teenage pregnancy, primiparity, low lower socioeconomic conditions, no antenatal care were higher in the mother with fetal malnutrition. Similar results were seen in the study done by Deodhar J et al for primiparityand adverse maternal age. ${ }^{20}$ Though the legal female marital age is declared to be 21 year by the government of Nepal, the median age of marriage is between $16-19$ years in Nepal. ${ }^{27}$ Early marriage will lead to primiparity at teenage. Due to the immaturity of the female reproductive system, inadequate prenatal weight gain, and in part by sociocultural and life style factors might result in the fetal malnutrition in the teenage mother. ${ }^{28}$ Lack of antenatal care in the mother deprives her from appropriate medical and nutritional counseling, and antenatal intervention for the preventable causes for the fetal malnutrition.

In our study, we found that babies of the vegetarian mothers had higher incidence of fetal malnutrition. In a study done by Koirala AK et al, it was found that vegetarian mother were more likely to give birth to low birth weight babies. ${ }^{29}$ Maternal nutrition during gestation, especially dietary protein intake, is a key determinant in embryonic survival, growth, and development. Low maternal dietary protein intake can cause embryonic losses, intra-uterine growth restriction, and reduced postnatal growth due to a deficiency in specific amino acids that are important for cell metabolism and function. The studies has shown the dietary supplementation amino acid like of Arginine during gestation has been effective in improving embryonic survival and development of the conceptus in humans. ${ }^{30}$ With the different socio-cultural value and poverty in the country like ours, the pregnant mothers have high chance of getting unbalanced diet. The vegetarian mothers are even more prone to get less protein from the unbalanced vegetarian diets. Rather than the type of the diet, it is very important to supply adequate protein diet for the pregnant woman considering their socioeconomic status, cultural acceptance and their choice of the diet.
In our study, adverse maternal condition like PIH, APH, UTI, fever during pregnancy, HBsAg positive status of mother had statistically significant impact in fetal malnutrition. The results were similar to the results by Adebami et al. ${ }^{8}$ Decreased utero-placental perfusion and increased inflammatory process present in the conditions like maternal infection, $\mathrm{PIH}$ and $\mathrm{APH}$, are the main culprit for abnormal intrauterine growth. ${ }^{31,32}$ The prevalence rate of maternal condition like DM and HIV were higher in the malnourished group but was statistically insignificant. As the effect of maternal diabetics may also lead to the baby with higher birth weight, the association may not be statistically significant. With the availability of good antiviral drugs against HIV, there might be less impact on fetal nourishment in utero.

The prevalence of history anemia was similar in the both group in our study. This could be explained by the various intervention carried by government to address the issue of anemia like supplementation of iron and folic acid, deworming for pregnant women and promotion of the use of mosquito nets in malaria-endemic areas that might have saved the fetus from the adverse effect of anemia in the utero. With the implementation of various strategies by Nepalese Government, the incidence rate of the anemia in the Nepalese pregnant woman has significantly decreased from $74 \%$ to $26 \%$.

\section{CONCLUSION}

The CAN score is the simple score that could be used to diagnose fetal malnutrition. The various maternal factors (teenage pregnancy, primiparit, low mid arm circumference, food habits) and disease conditions (PIH, APH, UTI, fever during pregnancy, HBsAg positive status of mother) are related to fetal malnutrition with statistical significance.

\section{LIMITATION OF THE STUDY}

The Canscore should be done to every newborn to assess the fetal nutritional status irrespective of birth weight. But,we could only assess the 400 term newborns in our study.

Being a single centered study done in the eastern part of Nepal, the known maternal factors causing FM in our study may vary due to different socioeconomic, cultural and geographical variations across the country.

\section{RECOMMENDATIONS}

There should be implementation of more accessible programs which address the issues of the maternal nutrition and the maternal health care that are the main cause of the fetal malnutrition. The implementation of health policies that expand maternal health services and nutritional education will have a great impact on the reduction of the fetal malnutrition and the breakage of the intergenerational cycle of malnutrition. 


\section{ACKNOWLEDGEMENTS}

We would like to acknowledge all our mothers of the newborns for trusting us and participating in the study. We are grateful to our nursing staffs of neonatal and maternal units for their constant support in our endeavours.

\section{REFERENCES}

1. Pediatrics AA of. Committee on fetus and newborn [Internet]. Vol. 6, Standards and Recommendations for Hospital Care of Newborn Infants. 1971. Available from: www.aappublications.org/news

2. Hughes MM, Black RE, Katz J. 2500-g Low Birth Weight Cutoff: History and Implications for Future Research and Policy. Matern Child Health J. 2017;21(2):283-9. DOI:10.1007/s10995-016-2131-9 PMID:27449779

3. Walther FJ, Ramaekers LHJ. The Ponderal Index as a measure of the nutritional Status at birth and its relation to some aspects of neonatal morbidity. J Perinat Med. 1982;10(1):42-7. DOI:10.1515/ jpme.1982.10.1.42

4. Lubchenco LO, Hansman C, Dressler M, Boyd E. Intrauterine growth as estimated. Pediatrics. 1963;32(5):793-800. DOI:10.1542/ peds. 102.1.S1.237 PMID:14075621

5. Adebami OJ, Owa JA. Comparison between CANSCORE and other anthropometric indicators in fetal malnutrition. Indian J Pediatr [Internet]. 2008 May;75(5):439-42. Available from: https://link. springer.com/article/10.1007/s12098-008-0069-7 DOI:10.1007/ s12098-008-0069-7 PMID:18537004

6. Singh $S$, Sood A. Assessment of Fetal Malnutrition and its proportion among AGA and SGA using CAN Score. J Med Sci Clin Res. 2018;06(06):902-7.

7. Metcoff J. Clinical assessment of nutritional status at birth: Fetal malnutrition and SGA are not synonymous. Pediatr Clin North Am [Internet]. 1994;41(5):875-91. Available from: http://dx.doi.org/ 10.1016/S0031-3955(16)38836-8 DOI:10.1016/ S0031-3955(16) 38836-8 PMID:7936778

8. Adebami OJ, Oyedeji GA, Owa JA, Oyelami OA. Maternal factors in the etiology of fetal malnutrition in Nigeria. Pediatr Int. 2007;49(2): 150-5. DOI:10.1111/j.1442-200X.2007.02328.x

9. Bernstein IM, Horbar JD, Badger GJ, Ohlsson A, Golan A. Morbidity and mortality among very-low-birth-weight neonates with intrauterine growth restriction. Am J Obstet Gynecol. 2000;182(1 I): 198-206. DOI:10.1016/S0002-9378(00)70513-8

10. Tsai LY, Chen YL, Tsou KI, Mu SC. The impact of small-for-gestationalage on neonatal outcome among very-low-birth-weight infants. Pediatr Neonatol. 2015 Apr 1;56(2):101-7. DOI:10.1016/ j.pedneo. 2014.07.007 PMID:25440777

11. Hill RM, Verniaud WM, Deter RL, Tennyson LM, Rettig GM, Zion TE, et al. The Effect of Intrauterine Malnutrition on the Term Infant: A 14-year Progressive Study. Acta Pædiatrica. 1984;73(4):482-7. DOI: 10.1111/j.1651-2227.1984.tb09959.x PMID:6540512

12. Levine TA, Grunau RE, McAuliffe FM, Pinnamaneni RM, Foran A, Alderdice FA. Early childhood neurodevelopment after intrauterine growth restriction: A systematic review. Vol. 135, Pediatrics. American Academy of Pediatrics; 2015. p. 126-41. DOI:10.1542/ peds.2014-1143 PMID:25548332

13. Von Beckerath AK, Kollmann M, Rotky-Fast C, Karpf E, Lang U, Klaritsch P. Perinatal complications and long-term neuro developmental outcome of infants with intrauterine growth restriction. Am J Obstet Gynecol [Internet]. 2013;208(2):130.e1130.e6. Available from: http://dx.doi.org/10.1016/ j.ajog. 2012.11. 014 DOI:10.1016/j.ajog.2012.11.014 PMID:23159694

\section{CONFLICT OF INTEREST}

There is no conflict of interest.

\section{FINANCIAL DISCLOSURE}

There are no financial conflicts of interest to disclose.

14. Bartels DB, Kreienbrock L, Dammann O, Wenzlaff P, Poets CF. Population based study on the outcome of small for gestational age newborns. Arch Dis Child Fetal Neonatal Ed. 2005 Jan;90(1). DOI:10.1136/adc.2004.053892 PMID:15613577

15. Barker DJP, Hales CN, Fall CHD, Osmond C, Phipps K, Clark PMS. Type 2 (non-insulin-dependent) diabetes mellitus, hypertension and hyperlipidaemia (syndrome $\mathrm{X}$ ): relation to reduced fetal growth. Diabetologia. 1993;36(1):62-7. DOI:10.1007/BF00399095 PMID:8436255

16. Rajeshwar Rao M, Balakrishna N, Visweswara Rao K. Suitability of CANSCORE for the assessment of the nutritional status of newborns. Indian J Pediatr.1999;66(4):483-92. DOI:10.1007/bf02727152 PMID:10798100

17. Katz J, Wu LA, Mullany LC, Coles CL, Lee ACC, Kozuki N, et al. Prevalence of Small-for-Gestational-Age and Its Mortality Risk Varies by Choice of Birth-Weight-for-Gestation Reference Population. Wright L, editor. PLoS One [Internet]. 2014 Mar 18 [cited 2020 Dec 2];9(3):e92074. Available from: https://dx.plos.org/ 10.1371/ journal.pone.0092074 DOI:10.1371/journal. pone.0092074

18. Naing L, Winn T, Rusli BN. Practical Issues in Calculating the Sample Size for Prevalence Studies. Vol. 1, Archives of Orofacial Sciences. 2006.

19. Singhal V, Agal P, Kamath N. Detection of fetal malnutrition by CAN Score at birth and its comparision with the other methods of determining intrauterine growth. Indian J Clin Pract. 2012;22(11): 576-82.

20. Deodhar J, Jarad R. Study of the prevalence of and high risk factors for fetal malnutrition in term newborns. Ann Trop Paediatr [Internet]. 1999;19(3):273-7. Available from: https://www.tandfonline. com/doi/abs/10.1080/02724939992365 DOI:10.1080/ 02724939992365 PMID:10715714

21. Faheem M, Saifuddeen A, Prakash. Comparative study of CANSCORE with Anthropometry in the assessment if fetal malnutrition. Int J Med Heal Sci. 2014;3(3):184-9.

22. Soundarya M, Basavaprabhu A, Raghuveera K, Baliga BS, Shivanagaraja BSV. Comparative assessment of fetal malnutrition by anthropometry and CAN score. Iran J Pediatr. 2012;22(1):70-6. PMID:23056862

23. Martínez-Nadal S, Demestre X, Raspall F, Vila C, Álvarez J, Sala P. Assessment of foetal nutrition status at birth using the CANS score. An Pediatría (English Ed. 2016;84(4). DOI:10.1016/j.anpede. 2015.09.033

24. Annual Report Departm ent of Health Serv ices Gov ernm ent of Nepal Ministry of Health and Population Departm ent of Health Serv ices Kathm andu. 2075.

25. M AJ, Jasim RD. Comparative study between Clinical Assessment of Nutritional status score ( CAN Score ) and Anthropometry in the assessment of Fetal malnutrition Comparative study between Clinical Assessment of Nutritional status score ( CAN Score ) and Anthropometry in. Intertnational Res J Med Sci. 2015;3(7):8-12.

26. Skokić $F$, Bačaj $D$, Selimović A, Hasanović E, Muratović S, Halilbašić A. Association of Low Birth Weight Infants and Maternal Socio demographic Status in Tuzla Canton during 1992-1995 War Period in Bosnia and Herzegovina. Int J Pediatr. 2010;2010:1-7. DOI:10.1155/ 2010/789183 
27. Aryal TR. Age at first marriage in Nepal: Differentials and determinants. J Biosoc Sci. 2007 Sep;39(5):693-706. DOI:10.1017/ S002193 2006001775 PMID:17156587

28. Roth J, Hendrickson J, Schilling M, Stowell DW. The Risk of Teen Mothers Having Low Birth Weight Babies: Implications of Recent Medical Research for School Health Personnel. J Sch Health [Internet]. 1998;68(7):271-5. Available from: https://pubmed. ncbi.nlm. nih.gov/9779401/ DOI:10.1111/j.1746-1561.1998. tb00581.x PMID:9779401

29. Koirala AK, Bhatta DN. Low-birth-weight babies among hospital deliveries in Nepal: a hospital-based study. Int J Womens Health [Internet]. 2015 Jun 8 ; 7:581. Available from: http://www. dovepress. com/ low-birth-weight-babies-among-hospital-deliveries-in-nepala-hospital--peer-reviewed-article-IJWH DOI:10.2147/IJWH.S84559
30. Herring CM, Bazer FW, Johnson GA, Wu G. Impacts of maternal dietary protein intake on fetal survival, growth, and development. Exp Biol Med. 2018;243:525-33. DOI:10.1177/1535370218758275

31. Getaneh T, Negesse A, Dessie G, Desta M. The impact of pregnancy induced hypertension on low birth weight in Ethiopia: systematic review and meta-analysis. Ital J Pediatr [Internet]. 2020 Dec 1;46(1):1-11. Available from: https://link.springer.com/ articles/ 10.1186/s13052-020-00926-0 DOI:10.1186/s13052-020-00926-0 PMID:33243285

32. Negrato CA, Gomes MB. Low birth weight: Causes and consequences. Vol. 5, Diabetology and Metabolic Syndrome. 2013. p. 49. DOI: 10.1186/1758-5996-5-49

33. Sossi F. Prevalence and Determinants of Undernutrition in Women in Nepal Dissertation Review. Acta Sci Nutr Heal. 2019;3(5):184-203. 